\title{
CD1D wt Allele
}

National Cancer Institute

\section{Source}

National Cancer Institute. CD1D wt Allele. NCI Thesaurus. Code C106494.

Human CD1D wild-type allele is located within 1q22-q23 and is approximately $6 \mathrm{~kb}$ in length. This allele, which encodes antigen-presenting glycoprotein CD1d, plays a role in glycolipid antigen presentation. 